\title{
Climate and nutrient influences on the growth of white spruce trees in the boreal forests of the Yukon
}

\author{
Rudy Boonstra ${ }^{1, *}$, Lanna Desantis ${ }^{1}$, Charles J. Krebs ${ }^{2}$, David S. Hik ${ }^{3}$ \\ ${ }^{1}$ Department of Biological Sciences, University of Toronto Scarborough, Toronto, Ontario M1C 1A4, Canada \\ ${ }^{2}$ Department of Zoology, University of British Columbia, Vancouver, British Columbia V6T 1Z4, Canada \\ ${ }^{3}$ Department of Biological Sciences, University of Alberta, Edmonton, Alberta T6G 2E9, Canada
}

\begin{abstract}
The boreal forests of North America are undergoing major changes because of the direct effects of global warming and increased $\mathrm{CO}_{2}$ levels. Plant production in the boreal forest is nutrient limited, and we examined how long-term fertilization affected growth of white spruce Picea glauca in the face of these major changes. We conducted a large-scale experiment by fertilizing two $1 \mathrm{~km}^{2}$ stands of white spruce in the southwestern Yukon with commercial NPK fertilizer from 1987 to 1994. Tree growth was measured by the width of annual increments in 60 trees from each of 2 control and of 2 matched fertilized $1 \mathrm{~km}^{2}$ sites for the period from 1977 to 1997 in a before, during, and after experimental design. Ring widths increased in both control and fertilized trees over this period as summer temperatures increased. Ring widths in fertilized trees increased from 9 to $48 \%$ over control trees during the years in which fertilizer was added, but immediately fell back to control levels from 1995 to 1997 at 1 site as soon as fertilization was stopped. In the long term, nitrogen in these forests may become tied up in shrubs, grasses, herbs, and fungi and not be available to the trees. There are 2 other possible explanations for this lack of sustained tree growth: first, the conversion of nitrogen into a form not readily available to spruce and, second, a spruce bark beetle outbreak that hit the southwestern Yukon during and after 1994 and affected 1 study site much more than the other.
\end{abstract}

KEY WORDS: Climate change $\cdot$ Nitrogen limitation $\cdot$ Picea glauca $\cdot$ Primary productivity $\cdot$ Spruce bark beetle $\cdot$ Tree ring widths $\cdot$ Yukon $\cdot$ Kluane Lake $\cdot$ White spruce

\section{INTRODUCTION}

The boreal forests of the northern hemisphere wreath the earth like a green halo, stretching from Fennoscandia and Russia to Alaska and across the entire breadth of Canada, occupying $11 \%$ of the earth's terrestrial surface (Bonan \& Shugart 1989). Three major factors are simultaneously affecting these forests: global warming caused by increasing carbon dioxide $\left(\mathrm{CO}_{2}\right)$ levels, increasing forest fire frequency, and changes in the community relationships between plant species and their natural enemies. Over the last $100 \mathrm{yr}$ (1906 to 2005), the earth's climate has warmed approximately $0.74^{\circ} \mathrm{C}$ and these are likely the greatest temperature gains of the last $1300 \mathrm{yr}$ (IPCC 2007). Computer model projections indicate that relative to 1980 to 1999 , the temperature by 2100 will increase between 1.8 and $4.0^{\circ} \mathrm{C}$ (range 1.1 to 6.4 ) and that these increases will be exacerbated at high latitudes. Indeed, in western North American arctic and boreal forest zones, average surface temperatures have increased $0.3^{\circ} \mathrm{C}$ per decade during the 20th century (Chapin et al. 2000) and in southwestern Yukon (the site of our study) the rate of warming may be accelerating, with spring temperatures (April to June) increasing nearly $2^{\circ} \mathrm{C}$ between 1975 and 2001 (Réale et al. 2003). This temperature increase may be a direct result of increasing $\mathrm{CO}_{2}$ levels. These levels have increased from the pre-industrial level of 280 to $379 \mathrm{ppm}$ in 2005 (IPCC 2007), exceeding levels seen over the past $650000 \mathrm{yr}$. Potentially, they will increase to between 540 and 970 ppm, depending on fossil fuel consumption levels, by the end of the 21st century (Houghton et al. 2001). Carbon sequestration by plants, and especially forests, 
through increased photosynthesis could dampen this atmospheric $\mathrm{CO}_{2}$ increase. However, the ability of plants to capitalize on this increase may be contingent on other limiting nutrients, particularly nitrogen (Reich et al. 2006), but possibly also phosphorus (Wassen et al. 2005).

The global nitrogen cycle has also been affected by human activities, resulting in the input of biologically reactive forms of nitrogen into the atmosphere and its subsequent deposition (Vitousek et al. 1997). Nitrogen deposition from these sources has major effects on biomes that are nitrogen limited, particularly forest communities (e.g. Högberg et al. 2006). The productivity of the boreal forest is believed to be nitrogen limited, and the addition of nitrogen alone often leads to increased productivity (Van Cleve et al. 1983, Bonan \& Shugart 1989), so that the addition of nitrogen from air pollution or from fertilizer ought to increase primary production. If this is correct, we need to determine for different regions of the boreal forest the quantitative response of trees and shrubs to nitrogen additions, and in particular the response in growth when nitrogen additions cease. Nemani et al. (2003) have shown net primary production in the global boreal forest zone has increased $6.6 \%$ over the period 1982 to 1999 in association with global warming and increased $\mathrm{CO}_{2}$ levels.

We examined the impact of long-term, large-scale NPK fertilizer application on the growth of white spruce trees Picea glauca in the southwestern Yukon. In contrast to the general climatic characterization of the boreal forest as having short, warm, moist summers (Bonan \& Shugart 1989), this region of the Yukon undergoes a pronounced water deficit during summer (Carrier \& Krebs 2002; their Fig. 1) as it lies in the rain shadow of the St. Elias Mountains (Rowe 1972). The signature of rising $\mathrm{CO}_{2}$ levels may be most evident in dry environments (Mooney et al. 1991) as found in white spruce from the southern limits of its distributional range in southern Manitoba (Wang et al. 2006). We have already reported the responses of the shrub and herb communities to these manipulations (Turkington et al. 1998, Krebs et al. 2001b). In addition, we document here the signature of global warming through an increase in tree growth independent of our fertilizer addition. Finally, we report the signature of the first attack of endemic spruce bark beetle Dendroctomus rufipennis that this region has experienced in the last 400 to 500 yr (Berg \& Henry 2003). The spruce bark beetle is the most significant insect agent of mortality of spruce trees in the northern latitudes of North America (Ford 1986), but had not caused any mortality in the northern Sakwak Trench of the Kluane area prior to 1994.

In the present study, we asked 3 questions: (1) Did spruce tree growth in the southwestern Yukon in- crease since 1982 as predicted by Nemani et al. (2003)? (2) How did spruce trees respond to nutrient additions, and how quickly did this response cease when nutrient addition ceased? (3) How much do climatic variations in temperature and precipitation affect spruce growth in comparison to the growth changes caused by nutrient additions?

\section{MATERIALS AND METHODS}

Our studies were carried out in the southwestern Yukon near the south edge of Kluane Lake $\left(61^{\circ} \mathrm{N}\right.$, $\left.156^{\circ} \mathrm{W}\right)$. Glaciation has been the dominant geological process determining the soils of the Kluane region (Krebs \& Boonstra 2001). During deglaciation large areas of outwash sediments were exposed to winds coming off the retreating glaciers. These sediments were wind-blown and deposited as loess on top of the glacial moraines. Loess in the Kluane region varies from 30 to $150 \mathrm{~cm}$ depth and is the basic soil material at all sites.

Two $1 \mathrm{~km}^{2}$ blocks of boreal forest, labeled Fertilizer 1 (= Flint) and Fertilizer 2 (= Grizzly), were selected for nutrient fertilization. Over the past $200 \mathrm{yr}$ there have been few large fires and a high frequency of small ones (Dale et al. 2001). Portions of the Flint area were burned in a fire in approximately 1924, and the Grizzly area supported an older forest stand from a possible fire around 1870. Aerial application by fixed-wing aircraft of granular commercial fertilizer was carried out annually from 1987 to 1994 between mid-May and early June. We monitored the uniformity of distribution and limitation of drift with test plots in 1988, and the pilots were very exact and drift was minimized (Krebs et al. 2001a). In 1987 and 1994 only nitrogen was added as ammonium nitrate at $25 \mathrm{~g}$ $\mathrm{N} \mathrm{m}^{-2}$. In 1988, 1990, and 1993 nitrogen was added as $\mathrm{NH}_{4} \mathrm{NO}_{3}$ at $17.5 \mathrm{~g} \mathrm{~m}^{-2}$; phosphorus, as $\mathrm{H}_{3} \mathrm{PO}_{4}$ at $5 \mathrm{~g} \mathrm{P}$ $\mathrm{m}^{-2}$; and potassium, as $\mathrm{K}_{2} \mathrm{O}$ (muriate of potash) at $2.5 \mathrm{~g} \mathrm{~K} \mathrm{~m}^{-2}$. Because of funding restraints, only half this amount could be added in 1989 and 1991, and none was added in 1992. From 1987 to 1994 (8 yr), cumulative totals of $120 \mathrm{~g} \mathrm{~N} \mathrm{~m}^{-2}, 20 \mathrm{~g} \mathrm{P} \mathrm{m}^{-2}$, and $10 \mathrm{~g}$ $\mathrm{K} \mathrm{m}^{-2}$ were added to these 2 plots. These application rates were within the range used in other long-term fertilization experiments (Weetman \& Fournier 1984, Kellner 1993). These nitrogen addition rates are about 750 times the annual atmospheric nitrogen wet deposition rates of $0.02 \mathrm{~g} \mathrm{~N} \mathrm{~m}^{-2} \mathrm{yr}^{-2}$ for nearby sites in interior Alaska (National Atmospheric Deposition Program, http://nadp.sws.uiuc.edu; Grünzweig et al. 2004). Natural mineralization rates in white spruce Picea glauca forests are about $4.7 \mathrm{~g} \mathrm{~N} \mathrm{~m}^{-2} \mathrm{yr}^{-1}$ (Binkley \& Hart 1989). 
White spruce trees in 4 areas $(\mathrm{N}=239$ trees, about 60 area $^{-1}$; Table 1) were sampled from May 25 to June 15, 1998. The areas were the 2 fertilizer treatment grids (Flint and Grizzly, $5 \mathrm{~km}$ apart) that were used by the Kluane Boreal Forest Ecosystem Project (Krebs et al. 2001a) and 2 unfertilized controls of similar forest structure and aspect, 1 paired adjacent to each of the 2 fertilizer sites. In Flint and Grizzly areas, a 20 by 20 checkerboard grid had been surveyed at $30 \mathrm{~m}$ spacing. Tree cores were taken in each of these 2 areas, near each grid point from A1 to A20, C1 to C20, and E1 to E20. Control trees for comparison were sampled from adjacent forest stands that did not receive any fertilizer. The control area for the Grizzly site was located $500 \mathrm{~m}$ across a small valley to the southwest of the fertilized site, and samples were taken at $30 \mathrm{~m}$ intervals to mimic the design of the fertilizer grid sampling. The control area for the Flint site was spread out to the east of the fertilized area (minimum $500 \mathrm{~m}$ distant from the fertilized area, sampled trees $30 \mathrm{~m}$ or more apart).

At each sampling location a tree core was taken from the white spruce closest to the systematically placed grid stakes (for the fertilized plots) or to the point $30 \mathrm{~m}$ from the previous tree sample (for the control areas). In order to sample both young and old trees, about half the trees chosen were $<5 \mathrm{~m}$ tall. The tree core was taken at a standard height of $80 \mathrm{~cm}$ above the ground to get a better estimate of age in these slow-growing spruce trees. This height should accurately reflect whole tree growth (Grabner \& Wimmer 2006). Diameter at breast height (DBH) was taken at $120 \mathrm{~cm}$ above the ground using a plastic tape measure. A second core was taken if the first missed the middle of the tree or broke. The height of trees that were cored was measured using a tape measure and an inclinometer. For small trees, height was measured directly with a meter stick. In all our statistical analyses, tree height was not a useful covariate, and $\mathrm{DBH}$ was a good covariate.

All tree cores were mounted and sanded, and the width of each annual ring was measured by the Tree Ring Increment Measuring System (TRIMS; Madera Software 1988) at the Department of Geography, University of Toronto.
Statistical analyses were carried out in NCSS (Number Cruncher Statistical System, available at: www. ncss.com/) and the various tests used are described in the 'Results' section. Weather data used here were recorded at the Haines Junction Meteorological Station, Yukon, $50 \mathrm{~km}$ southeast of the study site (for a summary see Krebs \& Boonstra 2001). This station receives about $300 \mathrm{~mm} \mathrm{yr}^{-1}$ precipitation, with most falling as rain in summer. Between 1965 and 2002 annual precipitation at the Burwash Airport $(50 \mathrm{~km}$ northwest of the study area) and at Haines Junction (50 km southeast) fluctuated with no clear trend, averaging 282 to $305 \mathrm{~mm} \mathrm{yr}^{-1}$ (Berg \& Henry 2003), and annual temperature over this period increased by $0.5^{\circ} \mathrm{C}$ every $10 \mathrm{yr}$ at both weather station sites (C. J. Krebs unpubl.).

\section{RESULTS}

White spruce Picea glauca tree density in the Kluane forests is very low by forestry standards. In the Flint area, trees $>10 \mathrm{~cm} \mathrm{DBH}$ averaged about $100 \mathrm{ha}^{-1}$; and in the Grizzly area, about $400 \mathrm{ha}^{-1}$. Trees selected for sampling were not similar in age, although they were similar in size (Table 1). In particular, trees in the Flint fertilizer area were only about 50 yr old on average, compared with 80 to $100 \mathrm{yr}$ at the other 3 sites. If ring widths change systematically with age or size in white spruce, we need to correct our measurements for age and size of each tree.

The original design of the study was a before, during, and after experimental design, with tree ring widths nested within individual trees and grid, fertilizer treatment, and year as factors. Unfortunately repeatedmeasures ANOVA could not be utilized because of a violation of the assumption of the equality of the covariance matrices among groups and a violation of the circularity assumption of the matrices. We therefore had to aggregate the data into a simpler design.

We constrained the ring width data from all trees to the period from 1977 to 1997 . To correct for the strong variation of tree ring width with age and size of trees, we used the analysis of covariance with both age of

Table 1. Picea glauca. Age and size structure of white spruce trees sampled in 4 areas of the Kluane region of southwestern Yukon. There is significant variation among groups in age but not in diameter

\begin{tabular}{|c|c|c|c|c|c|c|c|c|c|}
\hline \multirow{2}{*}{$\begin{array}{l}\text { Area and } \\
\text { treatment }\end{array}$} & \multirow[t]{2}{*}{$\mathrm{N}$} & \multicolumn{4}{|c|}{${ }_{-}$Age $(\mathrm{yr}) \longleftarrow$} & \multicolumn{4}{|c|}{ - Diameter $(\mathrm{cm})$} \\
\hline & & Mean & $\mathrm{SE}$ & Minimum & Maximum & Mean & SE & Minimum & Maximum \\
\hline Flint control & 59 & 90.2 & 8.5 & 12 & 285 & 12.2 & 0.9 & 3.9 & 27.3 \\
\hline Flint fertilized & 59 & 52.5 & 3.4 & 19 & 140 & 15.1 & 1.1 & 5.6 & 38.6 \\
\hline Grizzly control & 60 & 101.6 & 6.0 & 40 & 183 & 14.6 & 1.0 & 3.8 & 32.0 \\
\hline Grizzly fertilized & 61 & 80.8 & 5.8 & 28 & 209 & 14.6 & 1.0 & 4.5 & 34.1 \\
\hline
\end{tabular}


tree and DBH as covariates. In every analysis we carried out, these 2 covariates were highly significant. In contrast, the height of the tree did not add any additional information to explain variation in ring widths, so we omitted this variable from further analyses.

We first investigated if there was year to year variation in ring widths. We separated the 'before' data (1977 to 1986 ring widths) from the 'during fertilization' data (1987 to 1994) and the 'after' data (1995 to 1997). We used the analysis of covariance to adjust all ring widths to a fixed age and DBH of the tree. Fig. 1 shows ring widths for the 3 time periods for the 2 study areas.

During the 1977 to 1986 time period, when no treatments were applied, white spruce ring widths were significantly larger on the fertilized plots than on the control plots by 7 to $11 \%$. During the 1987 to 1994 time period, when fertilizer was being applied, the 2
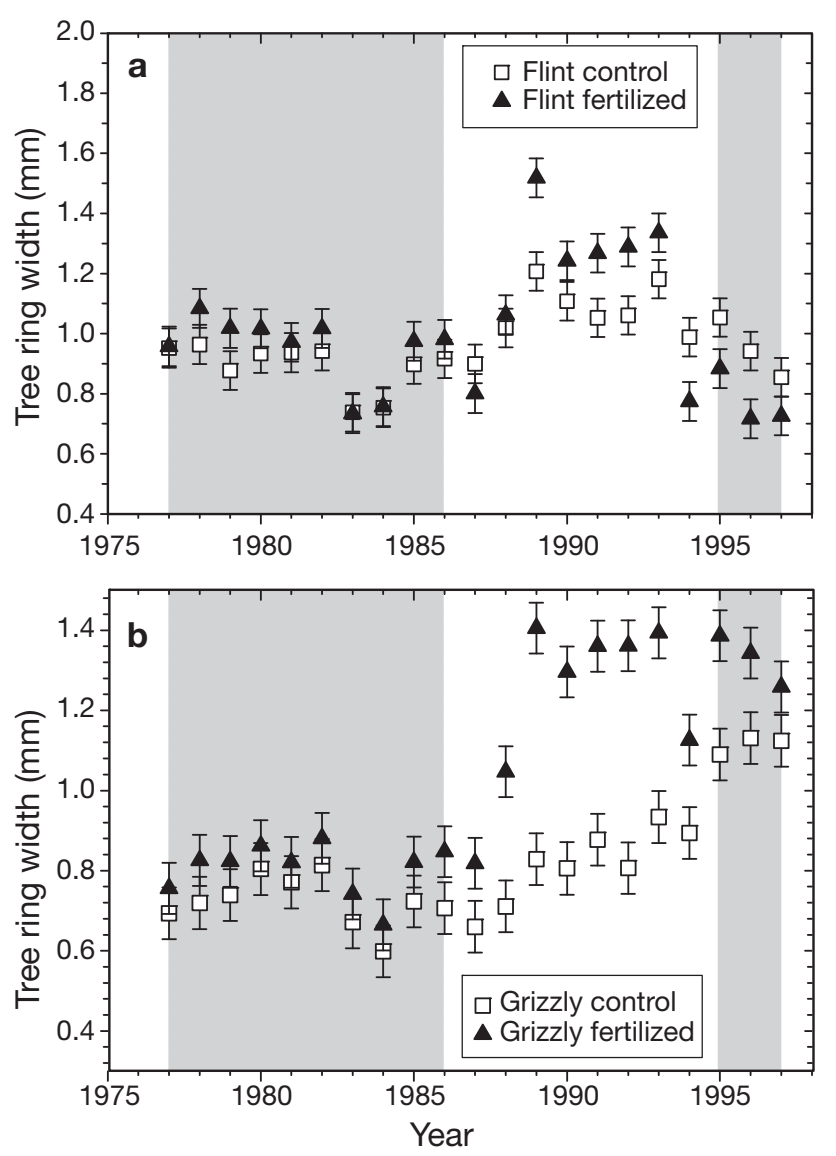

Fig. 1. Picea glauca. Average tree ring width for white spruce from 2 control and 2 paired fertilized areas in the Kluane region of the southwestern Yukon from 1977 to 1997. (a) Flint area and (b) Grizzly area. The pre-fertilization period from 1977 to 1986 is shaded, as is the post-fertilization period from 1995 to 1997. Ring widths were adjusted for age and DBH (diameter at breast height) by covariance. Each yearly point is an average based on 60 trees. Values are means \pm 1 SE study areas showed different responses. In the Grizzly area there was a strong response to fertilization. Ring widths increased $48 \%$ over controls at the Grizzly site, but only by $9 \%$ over controls at the Flint site (Table 2).

Fig. 1 shows that ring widths in the control trees also increased during the 1987 to 1994 fertilization period, and this trend is particularly clear at the Grizzly site. Since both control and experimental trees were growing faster during the fertilization time period, we need to determine why this might have occurred. The simplest hypothesis is that ring width is partly determined by tree age and size (which we corrected for by covariance), but this effect is completely overshadowed by changes in temperature and rainfall. We analyzed the year-to-year variation shown by control trees in Fig. 1 by multiple regression to see if we could predict ring growth from monthly temperature and rainfall records. Year-to-year variation in ring widths from 1977 to 1997 in control areas could be predicted most simply by May to July mean temperatures in both areas $\left(\mathrm{r}^{2}=0.67\right.$ for Grizzly, 0.56 for Flint, both $p<0.05$ ). Including rainfall data in the analysis did not increase the amount of variance that could be explained by multiple regression. Rising temperatures associated with climatic warming have stimulated tree growth in the Kluane region.

If fertilization increases tree growth in the boreal forest, the next question is how rapidly this stimulation disappears after fertilization stops. Fig. 2 shows the details of each of the $3 \mathrm{yr}$ from 1995 to 1997. In the fertilized Flint area, ring widths fell back to control values in 1995 and were below control values in 1996 and 1997. By contrast, in the Grizzly area, ring widths of fertilized trees remained well above those of control trees, with only a slow decay evident by 1997. Analysis of covariance for the 1995 to 1997 ring widths showed a strong interaction between treatment and area. DBH and age were controlled as covariates in this analysis. Thus, trees in Flint and Grizzly areas responded very differently to the cessation of fertilization for the period from 1995 to 1997. These observations are consistent

Table 2. Picea glauca. Average (mean) ring widths for white spruce trees in the fertilized and control areas during the period of fertilization (1987 to 1994) and after fertilization ended (1995 to 1997). Observed ring widths were adjusted for age and DBH (diameter at breast height) by covariance

\begin{tabular}{|c|c|c|c|c|}
\hline $\begin{array}{l}\text { Area and } \\
\text { treatment }\end{array}$ & $\begin{array}{l}\text { - During fe } \\
\text { Width (mm) }\end{array}$ & SE & $\begin{array}{l}\text { After fert. } \\
\text { Width (mm) }\end{array}$ & $\overline{\mathrm{SE}}$ \\
\hline Flint control & 1.164 & 0.026 & 1.006 & 0.038 \\
\hline Flint fertilized & 1.196 & 0.026 & 0.875 & 0.038 \\
\hline Grizzly control & 0.773 & 0.023 & 1.072 & 0.039 \\
\hline Grizzly fertilized & 1.135 & 0.022 & 1.234 & 0.038 \\
\hline
\end{tabular}



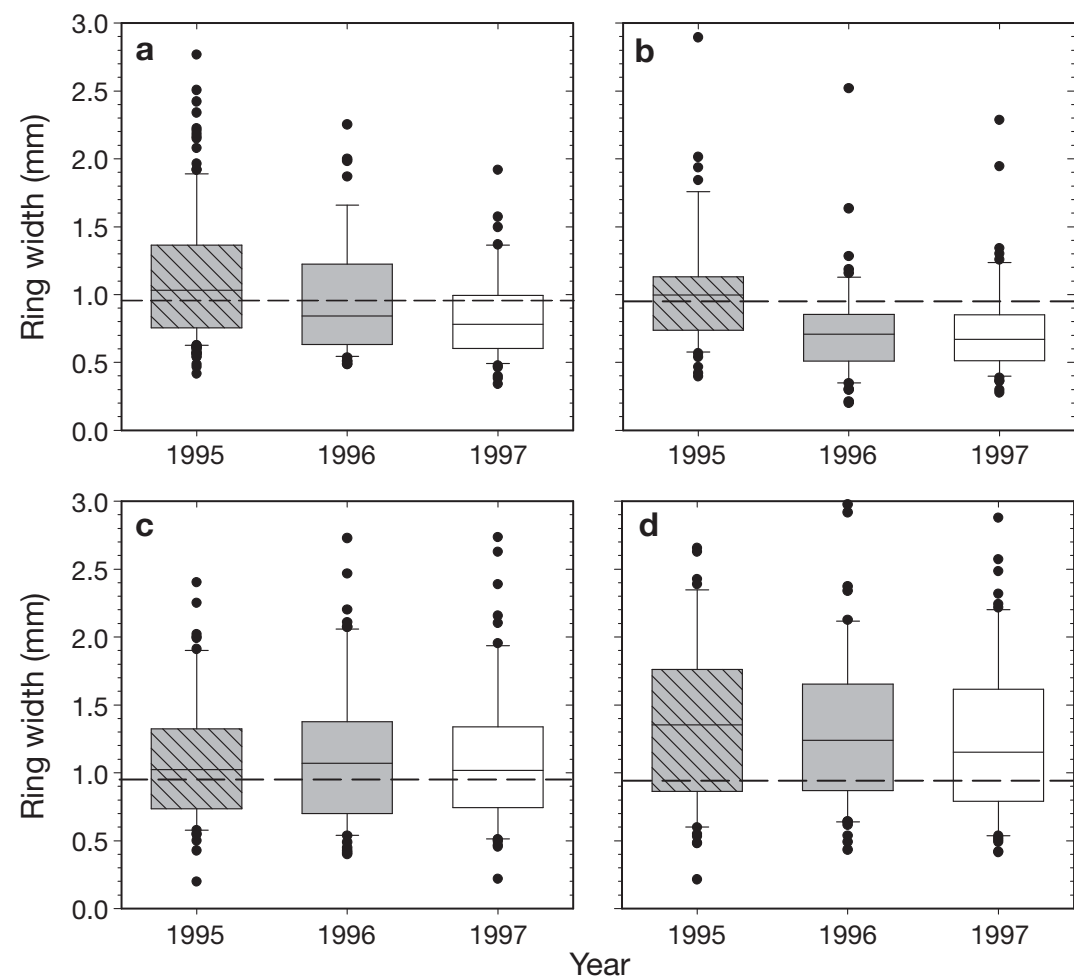

Fig. 2. Picea glauca. Box plots for tree ring widths for white spruce from 2 control and 2 paired fertilized areas showing detailed changes from 1995 to 1997 after fertilization was stopped (each year is uniquely shaded): (a) Flint control area, (b) Flint fertilized, (c) Grizzly control and (d) Grizzly fertilized. The dashed lines show the ring widths (adjusted for covariates age and DBH) for the entire data set for the 2 sites. Solid horizontal line: median; box: 25th to 75th percentiles; whiskers: 10th to 90th percentiles; dots: data points beyond the whiskers

with the hypothesis that the nutrients added during fertilization have been locked up by shrubs, herbs, and grasses, as well as by fungi, at the Flint site and thus became unavailable to white spruce trees.

\section{DISCUSSION}

No one doubts that tree growth in the boreal forest is limited by nutrients, and the conventional wisdom is that nitrogen is the critical limiting nutrient (Tamm 1991). However, since we used NPK fertilizer during the 8 yr period of fertilization, we cannot separate the impacts of the 3 different nutrients on tree growth. The key question is how much tree growth changes with nutrient additions in this part of the boreal forest, and how long stimulation will last after nutrient addition is stopped.

We have demonstrated 3 key findings. First, white spruce Picea glauca tree growth in the southwestern Yukon has increased in unmanipulated areas in response to an increase in early summer temperatures. This we presume to be a signature of climate change.
Second, white spruce tree growth can be accelerated by fertilization with NPK. Stimulation was forest-stand dependent, and younger spruce trees in a more open habitat (Flint) were not as nutrient limited as older trees in a less open habitat (Grizzly); hence, the latter responded more than the former (Fig. 1). Third, growth acceleration stopped almost immediately when fertilization stopped in the open forest stand (Flint), but decayed more slowly in the older forest stand (Grizzly) (Fig. 2).

One caveat that might confound our interpretation needs to be addressed. The mean tree age and growth differed between the control and fertilized areas, even prior to the fertilization period. In the Flint area (Table 1), the trees were much older and yet smaller in the control area than in the fertilized area. The mean diameter of the trees at sampling was about $3 \mathrm{~cm}(25 \%)$ greater in the Flint fertilized area and about $38 \mathrm{yr}$ $(42 \%)$ younger; respective values in the Grizzly area were a $0 \mathrm{~cm}$ difference in diameter and 21 yr $(20 \%)$ younger in the fertilized area. Thus, there were site-specific differences among the pairs, and part of these differences were related to the high heterogeneity in stand structure caused by fire (Dale et al. 2001). However, it is clear that despite these differences, the pattern of average tree growth was relatively constant prior to fertilization, increased in both members of the pair during the fertilization period, and did not change in a uniform way at all sites after fertilization stopped (Fig. 1). The analysis of covariance was used to control for differences in age and size of trees at the study sites, but it would have been better to have a more comparable age structure between control and fertilized trees.

Many experimental additions of nitrogen have been made in Scandinavia, particularly for Norway spruce Picea abies and Scots pine Pinus sylvestris, and virtually all of these experiments have shown that nitrogen is the most limiting nutrient (Nilsen \& Abrahamse 2003). What is striking in our results are the slow growth rates of white spruce in our region, even with fertilization. Fertilized trees increased in volume on average only about 1 to $2 \% \mathrm{yr}^{-1}$ more than control trees with an average of $15 \mathrm{~g} \mathrm{~N} \mathrm{~m}^{-2} \mathrm{yr}^{-1}$, compared with 30 to $40 \%$ more per year for Norway spruce fertilized with $9 \mathrm{~g} \mathrm{~N} \mathrm{~m}^{-2} \mathrm{yr}^{-1}$ for $4 \mathrm{yr}$ in southern Norway (Nilsen \& Abrahamse 2003). A pulsed fertilization 
experiment on red fir Abies magnifica in California produced 20 to $50 \%$ annual increases in volume growth during the first $10 \mathrm{yr}$ after fertilizer was added at $30 \mathrm{~g} \mathrm{~N} \mathrm{~m}^{-2}$ (Zhang et al. 2005).

Nemani et al. (2003) reported an average increase of net primary production of $6.6 \% \mathrm{yr}^{-1}$ for the period from 1983 to 1999 for the boreal zone. Our results for control trees indicate an average increase in white spruce ring widths of $1.6 \% \mathrm{yr}^{-1}$ for Flint and $5.1 \% \mathrm{yr}^{-1}$ for Grizzly over the period from 1983 to 1997 , values somewhat less than those reported by Nemani et al. (2003).

These findings on white spruce and those on other segments of the plant community in our area point to the need for a nutrient cycling analysis of the boreal forest ecosystem in the southwestern Yukon. The herbaceous understorey community responded strongly to a similar long-term addition, with certain species increasing markedly over a 10 yr period (Festuca altaica, Mertensia paniculata, Epilobium angustifolium, Achillea millefolium), whereas other species declined (Linnaea borealis, Lupinus arcticus, Arctostaphylous uva-ursi) (Turkington et al. 2002). The shrub community similarly responded strongly, and circumstantial evidence indicates that the added nutrients are still cycling within the shrub-soil component. We have measured shrub growth rates annually in grey willow Salix glauca and bog birch Betula glandulosa (the major shrub species in this area) since the cessation of fertilization in 1994 (Melnychuk \& Krebs 2005). Grey willows in the old, fertilized areas were growing 21 to $31 \%$ faster than willows at control sites in 2004 (Krebs unpubl. data), $10 \mathrm{yr}$ after fertilization had stopped. Similarly, bog birch in the old fertilized areas were growing 103 to $130 \%$ faster than birch shrubs at control sites in 2004. In some way these shrubs must be storing and recycling nutrients put into the system many years ago. This is echoed by work from Shaver et al. (2001) on long-term fertilization of arctic tundra that indicates that dwarf birch $B$. nana is an extremely effective competitor under conditions of high nutrients. The reason why white spruce is apparently not doing this is unknown, since nitrogen is often recycled within trees in nitrogen-limited ecosystems (Miller 1988).

A plausible explanation for the differential growth responses of segments of the plant community in the southwestern Yukon is that most of the nitrogen added was nitrified and that early successional/ruderal species (such as some of the herbs and grasses and the shrubs) were able to capitalize on this, whereas the late successional species (spruce and other herbs) were not. Plant families vary in their ability to utilize nitrogen sources (Smirnoff et al. 1984), ranging from extreme nitrate specialists (Chenopodeaceae, Rosaceae, Urticaceae) to ammonium specialists (Ericaceae, Pinaceae, Proteaceae). However, for any given species, family affiliation is hypothesized to be less important than its adaptation to the successional stage of the ecosystem and its specific requirements for a given nitrogen species (Britto \& Kronzucker 2002). White spruce has a widespread distribution and dominance in late-successional stages of temperate and boreal forests (Farrar 1995), but is excluded from disturbed, $\mathrm{NO}_{3}$-rich sites (see Kronzucker et al. 1997 for references). This is associated with an exceptionally poor utilization capacity for $\mathrm{NO}_{3}{ }^{-}$at the level of uptake, metabolism, and intracellular storage, whereas it shows superior growth on $\mathrm{NH}_{4}{ }^{+}$(Kronzucker et al. 1997). In temperate and boreal systems, soil $\mathrm{NO}_{3}{ }^{-}$ increases substantially after disturbances such as fire, clearcut harvesting, and windthrow (Vitousek et al. 1982, Kronzucker et al. 2003), whereas $\mathrm{NH}_{4}{ }^{+}$dominates the undisturbed soils in these systems (Blew \& Parkinson 1993). Thus, we suggest that in our area of the Yukon, the long-term fertilizer addition shifted the soils to those characteristic of an earlier successional stage and favored those plant species able to sequester nitrogen as $\mathrm{NO}_{3}{ }^{-}$.

An alternative explanation for the rapid decline in spruce growth after fertilization ceased was that nitrogen was lost through denitrification and hence was not available for sustained growth. We think this unlikely for 2 reasons. First, native rates of denitrification are very low in boreal soils, far exceeded by $\mathrm{N}$ inputs (Tamm et al. 1982), though they may have been augmented by fertilization. In a $120 \mathrm{yr}$ old white spruce stand, Blew \& Parkinson (1993) found very low rates of denitrification and argued that it did not represent substantial loss from the soil-plant system. Second, rates of denitrification are directly dependent on soil water content (Goodroad \& Keeney 1984) and the southwestern Yukon experiences a water deficit in summer (Carrier \& Krebs 2002). In 7 of 10 yr (from 1989 to 1998), Berg \& Henry (2003) report below average precipitation in summer.

The question of whether higher tree growth in fertilized forest stands will be maintained after the addition of nutrients is stopped has not been resolved, and yet is critical for prediction of the global carbon budget (Salih et al. 2005). In detailed studies of Norway spruce stands in Scandinavia, Salih et al. (2005) report poor ability of stands to retain nitrogen, which leads to the prediction that stands will quickly return to their base level of growth when fertilizer treatments cease. This is exactly what we observed at the Flint site during the present study (Fig. 1), but it is important to consider alternative explanations for our observations.

Ring widths dropped dramatically in all areas in 1994, in both controls and fertilized areas (Fig. 1), even though fertilizer was added in that year. It was not an anomalous year with respect to climate, as rainfall and 
temperature were not dramatically unusual. However, the Kluane region experienced a widespread outbreak of the spruce bark beetle in 1994 (Krebs \& Boonstra 2001, Berg \& Henry 2003) from an infestation that started in the southwestern Yukon in 1992 and the marked decline in ring widths may be a direct function of this insect attack. Ring widths decreased in the Flint area during 1995 to 1997 (relative to 1987 to 1993) on both control and fertilized trees, implying a dramatic decline to baseline levels as soon as fertilization stopped in 1994. But this result may also be confounded by the spruce bark beetle outbreak. The bark beetle outbreak has been patchy in the Kluane area, and white spruce trees in the Flint area were more strongly attacked by the bark beetle during this time period than trees in the Grizzly area (L. Desantis pers. obs.). The confounding effect of the bark beetle outbreak provides an alternative hypothesis for the observation that growth stimulation ceased as soon as fertilization stopped. The hypothesis is that fertilization increases the attractiveness of white spruce to insect attack (Popp et al. 1986), so that fertilized trees in this study were more likely to be attacked by the spruce bark beetle. The inference would be that the growth stimulation of nitrogen for the fertilized trees was countered by this additional insect attack, as observed by Rolland \& Lempérière (2004), so that the fertilized and control trees showed an equal growth response in the $3 \mathrm{yr}$ immediately after fertilization was stopped. This view could be tested by a repeated study of ring widths in the control and fertilized areas now that the bark beetle outbreak has largely passed this area and nearly 10 more years of growth are available for analysis. Van Cleve \& Zasada (1976) reported that white spruce in interior Alaska continued to grow after fertilization was stopped, contrary to our results for 1995 to 1997.

Tree rings have been used extensively to infer temperature changes in past centuries (Briffa et al. 2004), and our data are consistent with a temperature signature on tree ring widths (Fig. 1). Briffa et al. (1998) indicate that, on average, tree ring widths were rising during the 1970 s and 1980 s, similar to the data reported here. However, Briffa et al. (1998) point out that recent tree growth in the northern hemisphere has become less and less sensitive to temperature for reasons that are not clear. Gross photosynthesis measures of northern circumpolar high latitude ecosystems with satellite imaging over the last 20 yr (1982 to 2003) (Bunn \& Goetz 2006) generally showed no evidence of a net increase in photosynthesis in coniferous forests. Increased spring greening was balanced by late summer browning; the former may be related to increased spring temperatures, whereas the latter may be related to late summer water drought stress (Wilmking et al. 2004).
The recommendation arising from this research is to continue to monitor tree growth in the Kluane region of the Yukon to obtain a continuing measure of how tree growth responds to the changing climate on a local scale, to determine how long the nutrients provided in fertilizer from 1987 to 1994 might continue to stimulate growth of components of the community at Kluane and how this occurs through a nutrient cycling analysis, and to assist the global effort to determine patterns of tree ring-climate correlations (Briffa et al. 2004).

Acknowledgements. We thank Drs. D. Britto and H. Kronzucker for comments and Dr. J. Desloges, R. Dirszowsky, E. Raymond, and J. Werner for their assistance in preparing and measuring the tree cores. We thank E. Gold and J. Lindell for collecting the tree cores. This research was supported by the Natural Sciences and Engineering Research Council of Canada through a Collaborative Special Grant (to C.J.K. and the Kluane Team) and through Discovery Grants to R.B. and D.S.H. The Arctic Institute of North America provided facilities at Kluane Lake, Yukon, and we thank Andy Williams for his assistance. This is Publication No. 178 of the Kluane Boreal Forest Ecosystem Project.

\section{LITERATURE CITED}

Berg EE, Henry JD (2003) The history of spruce bark beetle outbreaks in the Kluane Region as determined from the dendrochonology of selected forest stands. Alaska Fish and Game Report NWR Kenai 4-2-2003. Available at: http://alaska.fws.gov/nwr/kenai/science/ExternalReps/ berg/kluanebeetle/kluanebeetle\%20report4-2-2003.pdf

Binkley D, Hart SC (1989) The components of nitrogen availability assessments in forest soils. Adv Soil Sci 10:57-112

$>$ Blew RD, Parkinson D (1993) Nitrification and denitrification in a white spruce forests in southwest Alberta, Canada. Can J For Res 23:1715-1719

> Bonan GB, Shugart HH (1989) Environmental factors and ecological processes in boreal forests. Annu Rev Ecol Syst 20:1-28

Briffa KR, Schweingruber FH, Jones PD, Osborn TJ and others (1998) Reduced sensitivity of recent tree-growth to temperature at high northern latitudes. Nature 391:678-682

Briffa KR, Osborn TJ, Schweingruber FH (2004) Large-scale temperature inferences from tree rings: a review. Global Planet Change 40:11-26

Britto DT, Kronzucker HJ (2002) $\mathrm{NH}_{4}{ }^{+}$toxicity in higher plants: a critical review. J Plant Physiol 159:567-584

Bunn AG, Goetz SJ (2006) Trends in satellite-observed circumpolar photosynthetic activity from 1982-2003: the influence of seasonality, cover type, and vegetation density. Earth Interact 10:1-19

Carrier P, Krebs CK (2002) Trophic effects of rainfall on Clethrionomys rutilus voles: an experimental test in a xeric boreal forest in the Yukon Territory. Can J Zool 80:821-829

Chapin FS III, McGuire AD, Randerson J, Piekle RS and others (2000) Arctic and boreal ecosystems of western North America as components of the climate system. Glob Change Biol 6(Suppl 1):211-223

Dale MRT, Francis S, Krebs CJ, Nams VO (2001) Trees. In: Krebs CJ, Boutin S, Boonstra R (eds) Ecosystem dynamics of the boreal forest: the Kluane project. Oxford University Press, New York, p 116-137

Farrar JL (1995) Trees in Canada. Fitzhenry and Whiteside, Markham 
Ford LB (1986) Dynamics of the spruce bark beetle (Dendroctomus rufipennis Kirby) in south-central Alaska. PhD dissertation, University of Washington, Seattle, WA

> Goodroad LL, Keeney DR (1984) Nitrous oxide production in aerobic soils under varying $\mathrm{pH}$, temperature, and water content. Soil Biol Biochem 16:39-43

> Grabner M, Wimmer R (2006) Variation of different tree-ring parameters in samples from each terminal shoot of a Norway spruce tree. Dendrochronologia 23:111-120

Grünzweig JM, Sparrows SD, Yakir D, Chapin FS III (2004) Impact of agricultural land-use change on carbon storage in boreal Alaska. Glob Change Biol 10:452-472

Högberg P, Fan H, Quist M, Binkley D, Tamm CO (2006) Tree growth and soil acidification in response to 30 years of experimental nitrogen loading on boreal forest. Glob Change Biol 12:489-499

Houghton JT, Ding Y, Griggs DJ, Noguer M and others (2001) Climate change 2001: the scientific basis. Contribution of Working Group 1 to the third assessment report of the Intergovernmental Panel on Climate Change. Cambridge University Press, Cambridge

IPCC (Intergovernmental Panel on Climate Change) (2007) WGI fourth assessment report: the physical basis. Summary for policy makers. Available at: www.ipcc.ch/

Kellner O (1993) Effects on associated flora of sylvicultural nitrogen fertilization repeated at long intervals. J Appl Ecol 30:563-574

Krebs CJ, Boonstra R (2001) The Kluane region. In: Krebs CJ, Boutin S, Boonstra R (eds) Ecosystem dynamics of the boreal forest: the Kluane project. Oxford University Press, New York, p 9-24

Krebs CJ, Boutin S, Boonstra R (eds) (2001a) Ecosystem dynamics of the boreal Forest. Oxford University Press, New York

Krebs CJ, Dale MRT, Nams VO, Sinclair ARE, O'Donoghue M (2001b) Shrubs. In: Krebs CJ, Boutin S, Boonstra R (eds) Ecosystem dynamics of the boreal forest: the Kluane project. Oxford University Press, New York, p 92-115

Kronzucker HJ, Siddiqi MY, Glass ADM (1997) Conifer root discrimination against soil nitrate and the ecology of forest succession. Nature 385:59-61

Kronzucker HJ, Siddiqi MY, Glass ADM, Britto DT (2003) Root ammonium transport efficiency as a determinant in forest colonization patterns: an hypothesis. Physiol Plant 117:164-170

Madera Software (1988) Tree-ring incremental measuring systems (TRIMS). Madera Software, Tuscon, AZ

Melnychuk MC, Krebs CJ (2005) Residual effects of NPK fertilization on shrub growth in a Yukon boreal forest. Can J Bot 83:399-404

Miller HG (1988) Long-term effects of application of nitrogen fertilizers on forest sites. In: Cole DW, Gessel SP (eds) Forest site evaluation and long-term productivity. University of Washington Press, Seattle, WA, p 97-106

> Mooney HA, Drake BG, Luxmoore RJ, Oechel WC, Pitelka LF (1991) Predicting ecosystem response to elevated $\mathrm{CO}_{2}$ concentrations. Bioscience 41:96-104

Nemani RR, Keeling CD, Hashimoto H, Jolly WM and others (2003) Climate-driven increases in global terrestrial net primary production from 1982 to 1999. Science 300: 1560-1563

Nilsen P, Abrahamse G (2003) Scots pine and Norway spruce stands responses to annual N, P and Mg fertilization. For Ecol Manag 174:221-232

Popp MP, Kulman HM, White EH (1986) The effect of nitrogen fertilization of white spruce (Picea glauca) on the yellow-headed spruce sawfly (Pikonema alaskansis). Can
J For Res 16:832-835

Réale D, McAdam AG, Boutin S, Berteaux D (2003) Genetic and plastic responses of a northern mammal to climate change. Proc R Soc Lond B Biol Sci 270:591-596

Reich PB, Hobbie SE, Lee T, Ellsworth DS and others (2006) Nitrogen limitation constrains sustainability of ecosystem response to $\mathrm{CO}_{2}$. Nature 440:922-925

Rolland C, Lempérière G (2004) Effects of climate on radial growth of Norway spruce and interactions with attacks by the bark beetle Dendroctonus micans (Kug., Coleoptera: Scolytidae): a dendroecological study in the French Massif Central. For Ecol Manag 201:89-104

Rowe JS (1972) Forest regions of Canada. Publ No 1300, Canadian Forest Service, Ottawa, Ontario

Salih N, Ågren GI, Hallbäcken L (2005) Modelling response of $\mathrm{N}$ addition on $\mathrm{C}$ and $\mathrm{N}$ allocation in Scandinavian Norway spruce stands. Ecosystems 8:373-381

Shaver GR, Bret-Harte MS, Jones MH, Johnstone LG and others (2001) Species composition interactions with fertilizer to control long-term changes in tundra productivity. Ecology 82:3163-3181

Smirnoff N, Todd P, Stewart GR (1984) The occurrence of nitrate reductase in the leaves of woody plants. Ann Bot 54:363-374

Tamm CO (1991) Nitrogen in terrestrial ecosystems. Ecological Studies 81, Springer-Verlag, Berlin

> Tamm CO, Lake JV, Miller HG (1982) Nitrogen cycling in undisturbed and manipulated boreal forest. Philos Trans R Soc Lond B Biol Sci 296:419-425

> Turkington R, John E, Krebs CJ, Dale MRT and others (1998) The effects of NPK fertilization for nine years on boreal forest vegetation in northwestern Canada. J Veg Sci 9: 333-346

Turkington R, John E, Watson S, Seccombe-Hett P (2002) The effects of fertilization and herbivory on the herbaceous vegetation of the boreal forest in north-western Canada: a 10-year study. J Ecol 90:325-337

Van Cleve K, Zasada JC (1976) Response of 70-year-old white spruce to thinning and fertilization in interior Alaska. Can J For Res 6:145-152

Van Cleve K, Oliver L, Schlentner R, Viereck LA, Dyrness CT (1983) Productivity and nutrient cycling in taiga forest ecosystems. Can J For Res 13:747-766

Vitousek PM, Gosz JR, Grier CC, Melillo JM, Reiners WA (1982) A comparative analysis of potential nitrification and nitrate mobility in forest ecosystems. Ecol Monogr 52: 155-177

Vitousek PM, Aber JD, Howarth RW, Likens GE and others (1997) Human alteration of the global nitrogen cycle: sources and consequences. Ecol Appl 7:737-750

Wang GG, Chhin S, Bauerle WL (2006) Effect of natural atmospheric $\mathrm{CO}_{2}$ fertilization suggested by open-grown white spruce in a dry environment. Glob Change Biol 12:601-610

Wassen MJ, Venterink HO, Lapshina ED, Tanneberger F (2005) Endangered plants persist under phosphorous limitation. Nature 437:547-550

Weetman GF, Fournier RM (1984) Ten-year growth and nutrition effects of a straw treatment and of repeat fertilization on jack pine. Can J For Res 14:416-423

> Wilmking M, Juday GP, Barber VA, Zald HSJ (2004) Recent climate warming forces contrasting growth responses of white spruce at treeline in Alaska through temperature thresholds. Glob Change Biol 10:1724-1736

Zhang J, Oliver WW, Powers RF (2005) Long-term effects of thinning and fertilization on growth of red fir in northeastern California. Can J For Res 35:1285-1293 